\title{
Evaluation of the Patients with spinal metastasis of unknown primary tumor origin
}

\author{
Alya A. Zobair \\ Department of Internal Medicine, College of Medicine, University of Mosul, Mosul, Iraq \\ Correspondence: aliaabdulaziz@uomosul.edu.iq
}

(Ann Coll Med Mosul 2020; 42 (2):119-125).

Received: $28^{\text {th }}$ Nove. 2020; Accepted: $21^{\text {th }}$ Dece. 2020.

\section{ABSTRACT}

Background: The spine is not only the most frequent site of skeletal metastasis of a known carcinoma but it is also the most frequent site of bone metastasis of unknown primary tumor origin, however, most of the existing reports that analyzed the clinical features of patients who presented with skeletal metastasis of unknown origin have included cases of bone metastasis at any location.

Objective: This study was conducted to analyze the clinical features, survival, and specific diagnostic implications in patients presented with spinal metastasis of unknown primary malignant tumor.

Method: In this prospective study, 40 patients presented with spinal metastasis of unknown primary tumor origin to Mosul Oncology Hospital were followed up.

Result: The primary malignant tumor was identified in $(97.5 \%)$ of cases, lung cancer was the most frequently identified primary tumor $(35 \%)$ followed by carcinoma of the breast $(30 \%)$ and prostatic cancer $(12.5 \%)$. We found that Computed tomography scan of the chest, abdomen and pelvis were the most useful diagnostic modality to identify the primary malignant tumor and there was a significant difference in the overall survival of patients with different primary tumor sites, shorter survival time was observed for aggressive tumor like lung cancer compared to patients having less aggressive primary tumor like breast and prostatic cancer.

Conclusion: Spinal metastasis of unknown primary carries a diagnostic challenge to the clinician, it is possible to detect the primary site in the majority of patients if we follow optimal diagnostic strategies. Detection of primary tumor site could help the clinician to provide the best therapeutic strategies.

Keywords: Spine, Metastasis, Unknown Primary.

$$
\begin{aligned}
& \text { تقيمّ المرضى الأين يعانون من ورم خبيث في العمود القفري من أصل ورم } \\
& \text { أولي غير معروف غين } \\
& \text { علياء عبد العزيز نجم ال زبيز }
\end{aligned}
$$

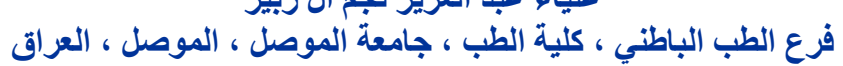

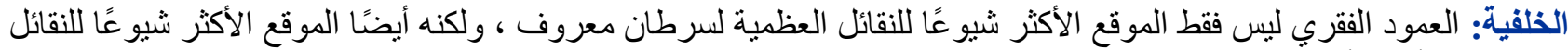

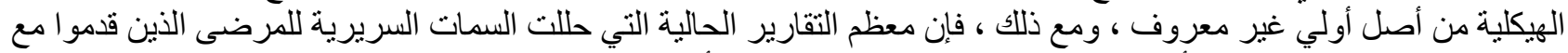

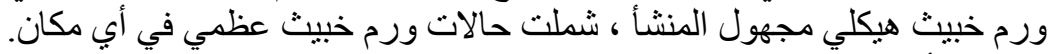

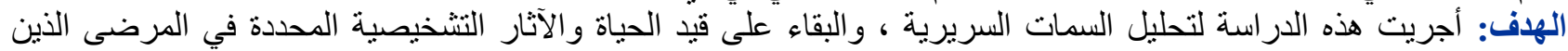

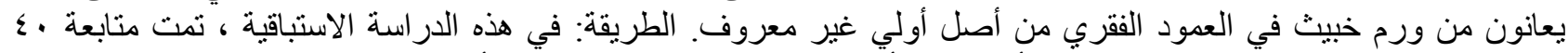

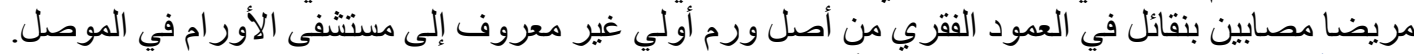

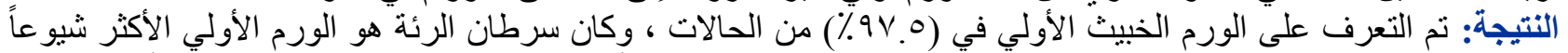

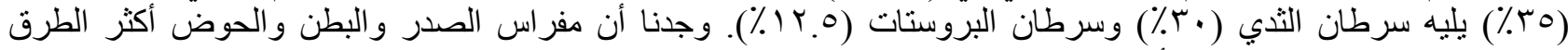

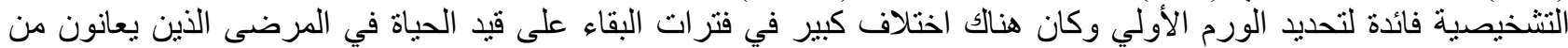

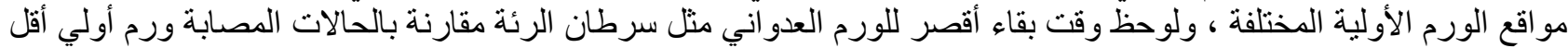

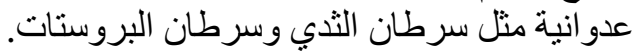




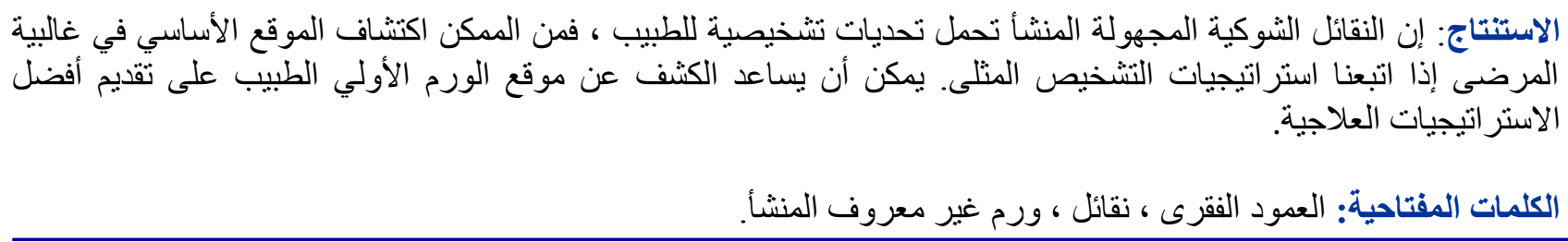

\section{INTRODUCTION}

he bone is the third most frequent distal site
of metastatic cancer after liver and lung, it could be the first manifestation of malignant tumor in about $25-30 \%$ of cancer patients. ${ }^{1,2}$ Any malignant tumor may metastasize to the skeleton, however, cancer that originate from epithelium is characterized by a particular propensity for bone metastasis, ${ }^{3-6}$ all literatures data reported that lung cancer is the most common identified cancer that metastasize to the bone. ${ }^{4-8}$ Other most frequent primary tumor that metastasize to bone are prostatic cancer, breast cancer, renal cell carcinoma and gastrointestinal tumors. ${ }^{4-8}$ The spine was reported to be the most frequent site of skeletal metastasis followed by pelvic bone and bones of extremities, ${ }^{6}$ and the majority of cases have multiple bone lesions, while solitary bone lesion occurred only in about $32.5 \%$. ${ }^{9,10}$

Although the treatment of patients with spinal metastases is palliative therapy in majority of cases, however, the opportunity of specific therapy could be opened in some cases when the primary tumor is successfully identified. ${ }^{11}$ In more than $85 \%$ of skeletal metastases of unknown primary cancer cases, the primary malignant tumor was identified following the diagnostic investigations, however it remained unknown in some cases despite extensive investigations. ${ }^{3}$

Diagnostic work up for those patients presented with bone metastasis of unknown primary tumor is overlapping with overall cancer of unknown primary workup. It includes medical history, physical examination, bone metabolism biochemical test, and Computed Tomography (C.T scan) of chest, abdomen and pelvis . ${ }^{2,13}$ The selection of other integrative investigation should be based on radiological and clinical finding like endoscopy, serum tumor markers, image guided biopsy and recently 18 FDG-PET scan (18 Ffluoro-deoxy glucose positron emission tomography) significantly enhanced the diagnostic accuracy of primary tumor. ${ }^{14}$

It has been reported that the spine is not only the most frequent site of skeletal metastasis of a known carcinoma but also it is the most frequent site of skeletal metastasis of unknown primary tumor origin, ${ }^{15,16}$ however most of the published reports on the skeletal metastasis of unknown primaries had included cases of bone metastasis at any location, therefore we conducted this study to analyze the clinical features and specific diagnostic and therapeutic implications in patients presented with spinal metastasis of unknown primary tumor origin.

\section{PATIENTS AND METHODS}

Forty patients who were presented with spinal metastasis of unknown primary tumor as first manifestation in Mosul Oncology hospital between 2017 and 2019 were included in this study. All the included cases had osteolytic

and/or sclerotic spinal lesions on MRI, no history of malignant disease and aged more than 18 years. All cases were followed up for at least 15 months. This prospective study was conducted in conformity to the Helsinki Declaration and was approved by the scientific Committee of College of Medicine/ University of Mosul.

After referral to oncology hospital, a medical evaluation for every patient was performed in 7 steps;

Step 1: medical history, general and systematic examination focusing on breast, thyroid gland and prostate.

Step 2: Laboratory test consist of blood electrolyte, bone metabolism chemical test, liver enzyme, renal function test, urine analysis, and complete blood count and ESR were determined.

Step 3: Serum Prostatic specific antigen PSA was determined for male patients. Others selected tumor markers level were determined in some patients like CEA (Carcinoembryonic antigen , CA19-9, CA 125 and AFP (Alpha Fetoprotein) .

Step 4: C.T. scan of the chest, abdomen and pelvis.

Step 5: Ultrasound of suspected site of origin.

Step 6: Tissue biopsy

Step 7: PET-CT scan

We prospectively analyzed the final diagnosis and survival of the patients, the overall survival duration was calculated from the time of first presentation with spinal metastasis to either the date of death or the date of last visit.

\section{Statistical Analysis}

SPSS was used for conducting the data management and statistical analysis (Version 20;SPSS). Kaplan-Meier test was used for survival analysis. 


\section{RESULT}

3.1 Patients characteristics: There were 19 male and 21 female patients with a mean age of 52 years $(S D=12.3)$ ranging from 29 to 78 years .

At time of initial presentation, 26 patients were presented with back pain only, while 14 patients were presented with symptoms of spinal cord compression according to the level of compression, like pain, numbness, cramping, loss of sensation or weakness in the lower limbs,

3.2 Location of skeletal metastasis: Spinal metastasis were solitary in $4(10 \%)$ cases and multiple in $36(90 \%)$ cases. Sixteen $(40 \%)$ cases have multiple metastasis involving whole spine, the site of multiple metastasis was limited to lumber spines in $12(30 \%)$ patients and to thoracic spines in $8(20 \%)$ patients.

3.3 Identification of Primary tumor: The primary malignant tumors were identified antemortem in 39 patients $(97.5 \%)$ of 40 patients presented with spinal metastasis of unknown primary tumor origin. The most frequently identified primary malignant tumor was lung carcinoma14 cases $(35 \%)$, others primary malignant tumor were; breast cancer 12 cases $(30 \%)$, Prostatic cancer 5 cases $(12.5 \%)$, one case for each of the following tumors, Multiple Myeloma (2.5\%), thyroid carcinoma, Ewing sarcoma, Lymphoma, Pancreatic cancer, Plasmacytoma , Hepatocellular carcinoma, and Malignant melanoma, as shown in table 1

Table (1): Primary malignant tumor.

\begin{tabular}{|l|l|l|}
\hline Primary malignancy & No. & $\%$ \\
\hline Lung cancer & 14 & 35 \\
\hline Breast cancer & 12 & 30 \\
\hline Prostatic cancer & 5 & 12.5 \\
\hline Multiple Myeloma & 1 & 2.5 \\
\hline Plasmacytoma & 1 & 2.5 \\
\hline Pancreatic cancer & 1 & 2.5 \\
\hline Hepatocellular carcinoma & 1 & 2.5 \\
\hline Ewing sarcoma & 1 & 2.5 \\
\hline Lymphoma & 1 & 2.5 \\
\hline Thyroid carcinoma & 1 & 2.5 \\
\hline Malignant Melanoma & 1 & 2.5 \\
\hline Unknown & 1 & 2.5 \\
\hline Total & 40 & $100 \%$ \\
\hline
\end{tabular}

The primary malignant tumor was not identified in 1 patient $(2.5 \%)$ despite extensive investigation including bone biopsy and PET-CT scan, and the patient's family refused autopsy.

\subsection{Diagnostic ability of clinical tests for detection of primary tumor:}

a-Initial medical examination was performed for all patients and identified the primary malignant tumor in 6 patients, 4 with breast mass and enlarged axillary lymph nodes, one patient with prostatic nodule and one patient with thyroid carcinoma as shown in table 2.
b-C.T. scan of the chest was performed for 35 patients and its findings were primary lung tumors in 10 cases, lung metastasis in 4 patients, pleural effusion in 3 patients, mediastinal lymph node enlargement in 2 patients.

c-C.T. scan of the abdomen and pelvis were performed for 21 patients and it identified 6 primary malignant tumors, 4 prostatic cancer, 1 pancreatic cancer, 1 Ewing sarcoma of iliac bone.

d-PSA was elevated in all cases with prostatic cancer, CA19.9 was elevated in 1 patient, CA15-3 was elevated in 4 patients, CA 125 was elevated in 2 patients, AFP was elevated in patient with hepatocellular carcinoma.

e-Ultrasound for suspected site of origin was also done, Ultrasound of the breast and axilla was performed for 14 patients and identified 12 patients with breast cancer, Ultrasound of thyroid gland was performed for 8 patients and identified 1 thyroid carcinoma, Ultrasound of abdomen performed for 18 patients and identified 1 patient with Hepatocellular carcinoma, secondary hepatic metastasis in 2 patients.

f- Spinal biopsy was taken from 19 patients, open biopsy was performed on 13 cases at time of decompression and spinal fixation, image guided Trucut biopsy was taken from spinal lesion on 6 patients and biopsy from tissue other than spinal lesion was performed on 21 patients.the histological result of spinal lesion is shown in table 3.

g-PET-CT was performed for 5 patients and identified 3 patients with lung cancer, 1 patient with Malignant Melanoma and other skeletal metastasis in 2 patients.

Table 2: Summary of baseline examinations

\begin{tabular}{|c|c|c|c|c|}
\hline $\begin{array}{l}\text { Diagnos } \\
\text { tic } \\
\text { studies }\end{array}$ & $\begin{array}{c}\text { No. } \\
\text { of } \\
\text { studi } \\
\text { es }\end{array}$ & $\begin{array}{l}\text { Cases } \\
\text { with } \\
\text { findings }\end{array}$ & Details & $\begin{array}{l}\text { No. of } \\
\text { cases }\end{array}$ \\
\hline $\begin{array}{c}\text { Physica } \\
\text { I } \\
\text { examin } \\
\text { ation } \\
\end{array}$ & 40 & 6 & $\begin{array}{l}\text { Breast cancer } \\
\text { Prostatic cancer } \\
\text { Thyroid tumor }\end{array}$ & $\begin{array}{l}4 \\
1 \\
1\end{array}$ \\
\hline $\begin{array}{l}\text { Chest } \\
\text { CT } \\
\text { scan }\end{array}$ & 35 & 20 & $\begin{array}{c}\text { Primary lung } \\
\text { cancer } \\
\text { Lung metastasis } \\
\text { Pleural effusion } \\
\text { Mediastinal LN } \\
\text { Pericardial effusion }\end{array}$ & $\begin{array}{l}10 \\
4 \\
3 \\
2 \\
1\end{array}$ \\
\hline $\begin{array}{c}\text { CT } \\
\text { scan of } \\
\text { abdome } \\
n \& \\
\text { pelvis }\end{array}$ & 21 & 9 & $\begin{array}{c}\text { HCC } \\
\text { Pancreatic tumor } \\
\text { Prostatic cancer } \\
\text { Ewing sarcoma of } \\
\text { iliac bone } \\
\text { Liver metastasis } \\
\text { Adrenal metastasis }\end{array}$ & $\begin{array}{l}1 \\
1 \\
3 \\
1 \\
2 \\
1\end{array}$ \\
\hline $\begin{array}{c}\text { U/S of } \\
\text { abdome } \\
n\end{array}$ & 18 & 3 & $\begin{array}{c}\text { HCC } \\
\text { Liver metastasis }\end{array}$ & $\begin{array}{l}1 \\
2\end{array}$ \\
\hline $\begin{array}{l}\mathrm{U} / \mathrm{S} \text { of } \\
\text { breast }\end{array}$ & 16 & 12 & $\begin{array}{c}\text { Breast mass } \\
\text { Axillary lymph node } \\
\text { enlargement }\end{array}$ & $\begin{array}{l}9 \\
5\end{array}$ \\
\hline PET-CT & 5 & 4 & $\begin{array}{c}\text { Lung cancer } \\
\text { Malignant } \\
\text { melanoma } \\
\text { Other skeletal } \\
\text { metastasis } \\
\text { Adrenal metastasis }\end{array}$ & $\begin{array}{l}3 \\
1 \\
3 \\
1\end{array}$ \\
\hline
\end{tabular}


Table 3: Histological diagnosis of spinal biopsy:

\begin{tabular}{|l|l|l|}
\hline Histological diagnosis & No. & $\%$ \\
\hline Adenocarcinoma & 10 & 52.6 \\
\hline Squamous cell carcinoma & 3 & 15.7 \\
\hline Undifferentiated carcinoma & 2 & 10.5 \\
\hline 5Small cell carcinoma & 1 & 5.2 \\
\hline Non- Hodgkin Lymphoma & 1 & 5.2 \\
\hline Malignant melanoma & 1 & 5.2 \\
\hline Plasmacytoma & 1 & 5.2 \\
\hline Total & 19 & 100 \\
\hline
\end{tabular}

3.5 Overall survival: The mean survival duration for all 40 patients was 13.6 months ranging from 430 months, shorter survival duration was reported for patient with hepatocellular carcinoma (4 months), the mean survival duration for patients with lung cancer was 6.6 months ranging from (5-9 months) and it is significantly shorter comparing with the survival duration for patients with breast and prostatic cancers ( $P$ value $=0.000$ ), This study showed that the mean survival duration for patients with breast cancer was 18.7 months ranging from 10-23 months, while for the prostatic cancer patients, the mean survival duration was 18.8 months ranging from $15-26$ months, as shown in figure 1.
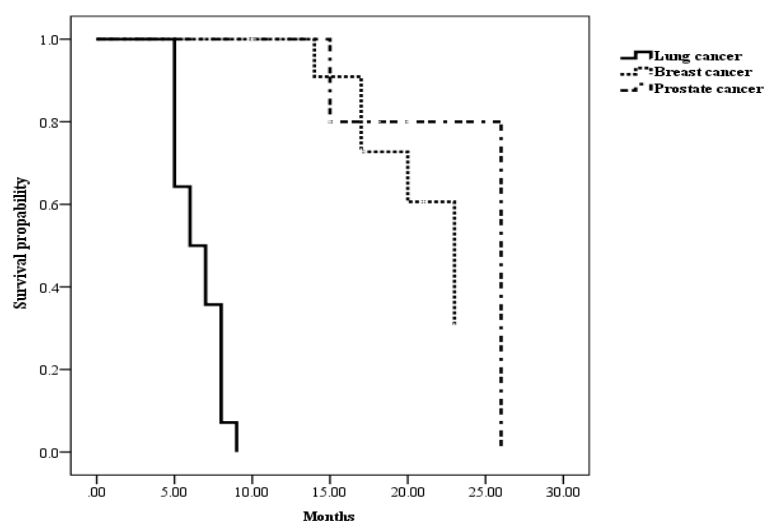

Figure 1: Kaplan-Meier plot showed the survival of patients with the commonest identified sites of primary tumor. $(P$ value $=0.000)$

\section{DISCUSSION}

Metastasis of occult primary tumor origin was occur in 2-3\% of all registered cancer cases in Iraq during the last few years, ${ }^{17,18}$ about $10-15 \%$ of cancer of unknown primary origin presented with bone localization. ${ }^{8,19,20}$

In this study, the primary malignancy has been identified in $(97.5 \%)$ of patients who presented with unknown primary tumor metastasis to spine, this detection rate is higher than that in numerous previous reports ( table 4 ), and this quit reasonable with the use of modern extensive investigations in the last few years.

Regarding the most common primary malignancy, our data demonstrated that carcinoma of the lung is the most frequently identified primary malignant tumor, this result is consistent with the result of the most previous studies, ${ }^{21-27}$ as shown in table 4. Interestingly, Vandecardelarate et al, noted a significant increase in the lung cancer frequency among patients with bone metastasis of unknown primary tumor in the last 40 years particularly among women, ${ }^{24}$ this is could be due to demographic effect of smoking.

Table 4: The frequency of identified primary tumor in bone metastasis in different studies

\begin{tabular}{|c|c|c|c|}
\hline Author & $\begin{array}{l}\text { BMUP } \\
\text { at } \\
\text { presen } \\
\text { tation }\end{array}$ & $\begin{array}{l}\text { Identifie } \\
d \\
\text { primary } \\
\text { site } \\
\end{array}$ & Site of identified PC \\
\hline $\begin{array}{l}\text { Current } \\
\text { study }\end{array}$ & 40 & $\begin{array}{c}39 \\
(97.5 \%)\end{array}$ & $\begin{array}{c}\text { Lung }(35 \%) \text {, breast }(30 \%) \text {, } \\
\text { prostate }(12.5 \%)\end{array}$ \\
\hline $\begin{array}{l}\text { Simon and } \\
\text { Bartucci } \\
(19)\end{array}$ & 46 & $\begin{array}{c}20 \\
(43.4 \%)\end{array}$ & $\begin{array}{l}\text { Lung }(35 \%) \text {, kidney }(13 \%) \text {, } \\
\text { breast }(4.3 \%) \text {, prostate }(\%)\end{array}$ \\
\hline $\begin{array}{l}\text { Shih et.al. } \\
\text { (21) }\end{array}$ & 52 & $\begin{array}{c}28 \\
(53.8 \%)\end{array}$ & $\begin{array}{c}\text { Lung }(32 \%) \text {, liver (15\%), } \\
\text { kidney }(9.5 \%), \text { prostate } \\
(9.5 \%)\end{array}$ \\
\hline $\begin{array}{l}\text { Rougraff } \\
\text { (22) }\end{array}$ & 40 & $\begin{array}{c}34 \\
(85 \%)\end{array}$ & $\begin{array}{c}\text { Lung }(57 \%), \text { kidney }(10 \%), \\
\text { breast }(2.5 \%)\end{array}$ \\
\hline $\begin{array}{l}\text { Jacobson } \\
\text { et.al. (23) }\end{array}$ & 29 & $\begin{array}{c}24 \\
(82.7 \%)\end{array}$ & $\begin{array}{l}\text { Lung }(37 \%) \text {, prostate } \\
(10.3 \%) \text {, breast }(6.8 \%)\end{array}$ \\
\hline $\begin{array}{l}\text { Katagiri } \\
\text { et.al. (9) }\end{array}$ & 64 & $\begin{array}{c}59 \\
(92.1 \%)\end{array}$ & $\begin{array}{l}\text { Lung }(35.9 \%), \text { prostate } \\
(17.1 \%), \text { breast }(7.8 \%)\end{array}$ \\
\hline $\begin{array}{l}\text { Vandecand } \\
\text { elaere (24) }\end{array}$ & 129 & $\begin{array}{c}84 \\
(65 \%)\end{array}$ & $\begin{array}{c}\text { Lung }(27.9 \%), \text { prostate } \\
(13.1 \%), \text { kidney }(11.6 \%) \\
\text { breast }(6.9 \%)\end{array}$ \\
\hline $\begin{array}{l}\text { Destombe } \\
\text { et.al. (6) }\end{array}$ & 152 & $\begin{array}{c}94 \\
(61.8 \%)\end{array}$ & $\begin{array}{l}\text { Lung }(24.3 \%), \text { prostate } \\
(17.1 \%), \text { breast }(13.1 \%)\end{array}$ \\
\hline Lizuka (25) & 27 & $\begin{array}{c}26 \\
(96 \%)\end{array}$ & $\begin{array}{c}\text { Myeloma (25.9\%), } \\
\text { lymphoma (11\%), Lung } \\
(22 \%)\end{array}$ \\
\hline $\begin{array}{l}\text { Takagi et.al. } \\
\text { (26) }\end{array}$ & 286 & $\begin{array}{c}254 \\
(88.8 \%)\end{array}$ & $\begin{array}{c}\text { Lung }(25.1 \%) \text {, Myeloma } \\
(14.3 \%), \text { prostate }(9 \%), \\
\text { lymphoma }(8 \%), \text { kidney } \\
(6.2 \%) \text {, liver }(4.1 \%),\end{array}$ \\
\hline
\end{tabular}

However, there is somewhat difference in the frequencies of other identified primary tumors, we found that breast cancer is the second identified primary malignant tumor, which is in consistent with the findings of the most previous studies, where breast cancer was reported to be the $3^{\text {rd }}$ or $4^{\text {th }}$ identified primary malignancy in patients with bone metastasis, ${ }^{9,19,28}$ this could be attributed to the difference in the inclusion criteria, in which we 
included patients with spinal metastasis only, which is the preferable secondary site for breast cancer metastasis, where spinal metastasis is account for two/ third of discovered bone metastasis in breast cancer, ${ }^{28}$ on the other hand, bone metastasis at any location had been included in other studies. Interestingly, breast cancer was the detected primary tumor in $12(57 \%)$ out of 21 included female patients in the present study, therefore we suggest to suspect breast cancer primary tumor in all female patients who will present with spinal metastasis of unknown origin.

Prostatic cancer with its high probability for bone metastasis ${ }^{29}$ was the $3^{\text {rd }}$ most frequently identified malignancy in this study, which is consistent with the results of most previous studies, ${ }^{19,21,26}$ but we did not identified any gynecological primary malignancy, similarly, most of previous studies showed that gynecological malignancy was rarely found to be the primary tumor. ${ }^{19,22,27}$

We found that CT scan of the chest was helpful diagnostic tool for the detection of 10 (71.4\%) out of 14 patients with lung cancer, a similar detection rate was reported by other study. ${ }^{9}$

Regarding abdominal lesions, although ultrasound of the abdomen is non-invasive and cheap diagnostic modalities, but we found that C.T scan of abdomen and pelvis is more beneficial in detecting malignant tumors in abdomen and pelvis, therefore, we recommend to omit ultrasound of abdomen if C.T. scan is available.

It is well known that ultrasound of breast is highly sensitive test for detection of breast carcinoma regardless the age of patients and density of breast, ${ }^{30}$ in this study, we found that ultrasound of breast and/or axilla were positive in all breast cancer cases, so we suggest that it is necessary to perform ultrasound of breast for all female patients presented with spinal metastasis of unknown origin.

We demonstrated that routine laboratory tests were beneficial for evaluation of general condition of patients but did not help in detection of primary tumor except for hematological malignancies. Tumor markers were elevated in 8 (20\%) out of 40 included cases with spinal metastasis of unknown primary tumor.

Serum PSA level was abnormally elevated in all 5 included patients with prostatic cancer, so we found it more beneficial than imaging tests, and this higher specificity of PSA is consistent with previous reports, ${ }^{9,26}$ additionally Freedland SJ demonstrated that PSA is playing important roles in therapeutic response and early detection of recurrence. ${ }^{31}$

Other relatively specific tumor markers for specific malignancy were also elevated, AFP and CA19-9 were elevated in patient with hepatocellular carcinoma and pancreatic cancer respectively, however we couldn't analyze this result due to small sample size.

PET-CT scan is a relatively recently introduced diagnostic modality, it is a combined FDG-PET/CT scanner allows gaining both functional and anatomical imaging in a single test. ${ }^{32}$ Since PETCT scan is relatively expensive and not available in our hospital, PET-CT scan was done as a final step to identify the primary malignant tumor in the included cases with spinal metastasis,

Previous studies had investigated the detection rate for FDG-PET of primary tumor in patient with unknown primary origin, the detection rate was observed between $24-43 \%$, the specificity was observed between $71-81 \%$ while the sensitivity was observed between $87-91 \%$. ${ }^{33-35}$ However, Takagi et al found that FDG/PET is not more beneficial than CT scan in detecting primary tumor in $_{26}$ cases with bone metastasis of unknown primary.

In this study, PET-CT scan was ordered for 5 patients in whom the primary tumors were settled in 4 cases $(80 \%)$, this is quite expected since the addition of anatomical data obtained in PET-CT increased the accuracy of detection rate comparing with CT scan or FDG/PET alone. ${ }^{36}$

Regarding the location of spinal metastasis, we found that lumber spine was the most frequent site of spinal metastasis of unknown primary, followed by thoracic spine, this result is different from the result of Sagban et al which included 5 cases with spinal metastasis of unknown primary and showed that dorsal metastasis is more frequent followed by lumber metastasis. ${ }^{37}$ While Abdurrahman $A$. et al found the same frequency of occurrence of lumber and dorsal metastasis in 25 cases with spinal metastasis of unknown origin, ${ }^{38}$ this difference could be due to the small sample size which included in their studies.

In the survival analysis of this study, we found that there were a significant difference in the overall survival in patients with different primary tumor sites, shorter survival time was observed for aggressive tumor like lung cancer compared to patients having less aggressive primary tumor like breast and prostatic cancer, similar result was observed by Takagi et al study which studied the survival time for each tumor type in patients who presented with skeletal metastasis of occult primary. ${ }^{26}$ Furthermore, Raholpak et al reported that poor survival outcome is observed in patient with skeletal metastasis if synergistic visceral metastasis is also present. ${ }^{2}$ Therefore, with the respect of survival, the clinician may be able to choice intensive therapy for patient with good prognosis. 


\section{CONCLUSION}

Spinal metastasis of unknown primary carries a diagnostic challenges to the clinician, it is possible to detect the primary site in the majority of cases if optimal diagnostic strategies were followed, the most identified primary tumor was lung carcinoma followed by breast and prostatic cancer. Survival outcome is mainly affected by the aggressiveness of primary carcinoma, therefore, detection of primary tumor site could help the clinician to provide the best therapeutic strategies.

\section{Acknowledgment}

This study was supported by Department of Medicine, College of Medicine, University of Mosul.

\section{REFERENCES}

1.Piccioli A. Breast cancer: bone metastases an orthopedic emergency. J Orthopaed Traumatol. 2014;15(2):143-44.

2.Paholpak P., Sirichativapee W., Wisanuyotin T., Kosuwon W., Jeeravipoolvarn P. Prevalence of Known and Unknown Primary Tumor Sites In Spinal Metastasis Patients. Orthop J. 2012 ; 6:440-4.

3.Hess K.R., Abbruzzese, M.C., Lenzi, R., Raber, M.N., Abbruzzese, J.L. Classification and regression tree analysis of 1000 consecutive patients with unknown primary carcinoma. Clin. Cancer Res. 1999; 5, 3403-10.

4. Carretero R.G., Brugera M.R., Rebollo-Aparicio N., Mohamed L.E.B. Primary bone metastasis as first manifestation of an unknown primary tumour. BMJ Case Rep. 2015; 2015: bcr2015211302. doi: 10.1136/bcr-2015-211302.

5.Piccioli A., Maccauro G., Spinelli M.S., Biagini R., Rossi B. Bone metastases of unknown origin: Epidemiology and principles of management. $\mathrm{J}$. Orthop. Traumatol. 2015; 16(2):81-6.

6.Destombe C., Botton E., Le Gal G., Roudaut A., Jousse-Joulin S., Devauchelle-Pensec V., Saraux, A. Investigations for bone metastasis from an unknown primary. Jt. Bone Spine. 2007; 74(1): 85-9.

7.Kodaira M., Takahashi S., Yamada S., Ueda K., Mishima Y., Takeuchi K., Yamamoto N., Ishikawa Y., Yokoyama M., Saotome T., et al. Bone metastasis and poor performance status are prognostic factors for survival of carcinoma of unknown primary site in patients treated with systemic chemotherapy. Ann. Oncol. 2010; 21(6):1163-7.

8. Hemminki K., Riihimäki M., Sundquist K., Hemminki A. Site-specific survival rates for cancer of unknown primary according to location of metastases. Int. J. Cancer. 2013; 133(1):1829.
9. Katagiri H., Takahashi M., Inagaki J., Sugiura $\mathrm{H}$., Ito $\mathrm{S}$., Iwata $\mathrm{H}$. Determining the site of the primary cancer in patients with skeletal metastasis of unknown origin: a retrospective study. Cancer. 1999; 86(3):533-7.

10. Simon M.A., Bartucci E.J. The Search for the Primary Tumor in Patients With Skeletal Metastases of Unknown Origin. Cancer. 1986; 58(5):1088-95.

11. Argentiero A., Solimando A.G., Brunetti O., Calabrese A., Pantano F., Iuliani M. , Santini D., Silvestris N., Vacca A. Skeletal Metastases of Unknown Primary: Biological Landscape and Clinical Overview. Cancers. 2019; 11(9): 1270.

12. Bochtler T., Lö_er H., Krämer A. Diagnosis and management of metastatic neoplasms with unknown primary. Semin. Diagn. Pathol. 2018; 35(3):199-206.

13. Bender R.A., Erlander M.G. Molecular Classification of Unknown Primary Cancer. Semin. Oncol. 2009; 36(1):38-43.

14. Kwee, R.M. Combined FDG-PET/CT for the detection of unknown primary tumors: Systematic review and meta-analysis. Eur. Radiol. 2009; 19(3):731-44.

15. Ugras N., Yalcinkaya U., Akesen B., Kanat O. Solitary bone metastases of unknown origin. Acta Orthop Belg. 2014; 80(1):139-43.

16. Khan M.N., Sharfuzzaman A., Mostafa M.G. Spinal cord compression as initial presentation of metastatic occult follicular thyroid carcinoma. J Neurosci Rural Pract. 2014; 5(2):155-9

17. Iraqi Cancer Registry Center Publications. Ministry of Health , Iraqi Cancer Board. Baghdad, Iraq, 2018, P 27.

18. Iraqi Cancer Registry Center Publications.Ministry of Health, Iraqi Cancer Board. Baghdad, Iraq, 2017, P 50.

19. Simon M.A., Karluk M.B. Skeletal metastases of unknown origin. Diagnostic strategy for orthopedic surgeons. Clin Orthop Relat Res. 1982; 166:96-103

20. Le Chevalier T, Cvitkovic E, Caille P, Harvey J, Contesso G, Spielmann M, Rouesse J. Early metastatic cancer of unknown primary origin at presentation. A clinical study of 302 consecutive autopsied patients. Arch Intern Med. 1988; 148(9):2035-9.

21. Shih L.Y., Chen T.H., Lo W.H., Shih L., Chen T., Lo W. Skeletal metastasis from occult carcinoma. J. Surg. Oncol. 1992; 51(2):109-13.

22. Rougraff B.T., Kneisl J.S., Simon M.A. Skeletal metastases of unknown origin. A prospective study of a diagnostic strategy. J Bone Jt Surg Am. 1993; 75(9):1276-81.

23. Jacobsen S., Stephensen S.L., Paaske B.P., Lie P.G., Lausten G.S. Skeletal metastases of 
unknown origin: A retrospective analysis of 29 cases. Acta Orthop. Belg. 1997; 63(1): 15-22.

24. Vandecandelaere M., Flipo R.M., Cortet B., Catanzariti L., Duquesnoy B., Delcambre B. Bone metastases revealing primary tumors. Comparison of two series separated by 30 years. Jt. Bone Spine. 2004 ; 71(3): 224-29.

25. lizuka, Y.; lizuka, H.; Tsutsumi, S.; Nakagawa, Y.; Nakajima, T.; Sorimachi, Y.; Ara, T.; Nishinome, M.; Seki, T.; Takagishi, K. Diagnosis of a previously unidentified primary site in patients with spinal metastasis: Diagnostic usefulness of laboratory analysis, CT scanning and CT-guided biopsy. Eur. Spine J. 2009; 18(10): 1431-5

26. Takagi, T.; Katagiri, H.; Kim, Y.; Suehara, Y.; Kubota, D.; Akaike, K.; Ishii, M.; Mukaihara, K.; Okubo, T.; Murata, H.; et al. Skeletal Metastasis of Unknown Primary Origin at the Initial Visit: A Retrospective Analysis of 286 Cases. PLoS ONE. 2015; 10, e0129428.

27. Nottebaert M., Exner G.U., von Hochstetter A.R., Schreiber A. Metastatic bone disease from occult carcinoma: a profile. Int Orthop. 1989; 13(2):119-23

28. Ju D.G., Yurter A., Gokaslan Z.L., Sciubba D.M. Diagnosis and surgical management of breast cancer metastatic to the spine. World $\mathrm{J}$ Clin Oncol. 2014; 5(3): 263-71.

29. Heindel W., Gübitz R., Vieth V., Weckesser M., Schober O., Schäfers M. The Diagnostic Imaging of Bone Metastases. Dtsch Arztebl Int. 2014 ; 111: 741-7.

30. Tan K.P., Azlan Z.M., Choo M.Y., Rumaisa' M.P., Siti 'Aisyah Murni M.R., Radhika S., Nurismah M.I., Norlia A., Zulfiqar M.A. The Comparative Accuracy of Ultrasound and Mammography in The Detection of Breast Cancer. Med J Malaysia. 2014; 69(2):79-85.

31. Freedland S.J., Hotaling J.M., Fitzsimons N.J., Presti J.C., Kane C.J., Terris M.K., Aronson W.J., Amling C.L. PSA in the new millennium: a powerful predictor of prostate cancer prognosis and radical prostatectomy outcomes results from the SEARCH database. Eur Urol. 2008; 53(4):758-64.

32. Blodgett T.M., Meltzer C.C., Townsend D.W. PET/CT: form and function. Radiology. 2007; 242(2):360-85.

33. Sève P., Billotey C., Broussolle C., Dumontet C., Mackey J.R. The role of 2-deoxy-2-[F18]fluoro-D-glucose positron emission tomography in disseminated carcinoma of unknown primary site. Cancer. 2007; 109(2):2929

34. Rusthoven K.E., Koshy M., Paulino A.C. The role of fluorodeoxyglucose positron emission tomography in cervical lymph node metastases from an unknown primary tumor. Cancer. 2004; 101(11):2641-9.

35. Delgado-Bolton R.C., Fernández-Pérez C., González-Maté A., Carreras J.L. Meta-analysis of the performance of 18F-FDG PET in primary tumor detection in unknown primary tumors. $J$ Nucl Med. 2003; 44(8):1301-4.

36. Kwee T.C., Kwee R.M. Combined FDGPET/CT for the detection of unknown primary tumors: systematic review and meta-analysis. Eur Radiol. 2009;19(3):731-44.

37. Sagban W.J., Ridha S.M.S., Hasan Z.N. Comparison between Metastatic Spinal Tumour of Unknown Primary Tumour with a Known Primary. World Journal of Neuroscience. 2016; 6, 18-22.

38. Aycan A., Celik S., Kuyumcu F., MAkyol M.E., Dogan E., HarunArslan H. Spinal Metastasis of unknown primary Accompanied by Neurologic Deficit of Vertebral Instability. World Neurosurgery. 2018; 109, e33-e42. 